\title{
Microbiological quality of milk sold directly from producers to consumers
}

\author{
R. Pyz-Łukasik, ${ }^{* 1}$ W. Paszkiewicz, ${ }^{*}$ M. R. Tatara,† P. Brodzki, $\ddagger$ and Z. Bełkot* \\ *Department of Food Hygiene of Animal Origin, Faculty of Veterinary Medicine, University of Life Sciences in Lublin, ul. Akademicka 12, \\ 20-950 Lublin, Poland \\ †Department of Animal Physiology, Faculty of Veterinary Medicine, University of Life Sciences in Lublin, ul. Akademicka 12, 20-950 Lublin, Poland \\ ‡Department and Clinic of Reproduction, Faculty of Veterinary Medicine, University of Life Sciences in Lublin, ul. Głęboka 30, 20-612 Lublin, \\ Poland
}

\begin{abstract}
The aim of this study was to determine the microbiological quality of raw cow milk from direct sale points. Raw cow milk samples were collected from 5 randomly selected direct sale points for microbiological evaluation. The samples were analyzed to determine total aerobic bacterial count, somatic cell count (SCC), counts of Enterobacteriaceae, Enterococcus, Escherichia coli, and Staphylococcus, and presence of Salmonella, Listeria monocytogenes, and inhibitory substances. The mean counts of total aerobic bacterial in samples from all direct sale points were between $9.2 \times 10^{4}$ and 3.6 $\times 10^{7} \mathrm{cfu} / \mathrm{mL}$. Milk samples collected from 5 direct sale points revealed counts Enterobacteriaceae ranging from $6.4 \times 10^{1}$ to $1.7 \times 10^{6} \mathrm{cfu} / \mathrm{mL}$. Escherichia coli were detected in 12 milk samples with counts ranging from $5.0 \times 10^{0}$ to $1.1 \times 10^{2} \mathrm{cfu} / \mathrm{mL}$. Staphylococcus spp. bacteria were found in all milk samples, at counts ranging from $1.6 \times 10^{3}$ to $5.1 \times 10^{4} \mathrm{cfu} / \mathrm{mL}$. Listeria monocytogenes bacteria were detected in 1 sample, and SCC in all samples ranged from 78,000 to $1,730,000 /$ $\mathrm{mL}$. The examined samples did not contain Salmonella rods or inhibitory substances. In the samples examined in this study, international hygiene standards were exceeded for total aerobic bacterial count $(\mathrm{n}=48)$ as well as for SCC ( $\mathrm{n}=19)$. Two milk samples contained pathogenic bacteria (Listeria monocytogenes and Staphylococcus aureus) that pose a potential hazard for consumer health.
\end{abstract}

Key words: raw milk, microbiological quality of milk, somatic cells, inhibitory substances in milk

\section{INTRODUCTION}

In the European Union, the hygiene standards of raw milk from cows and other animals are defined

Received December 3, 2014.

Accepted March 22, 2015.

${ }^{1}$ Corresponding author: renata.pyz@up.lublin.pl by regulation. According to appendix III, section IX, chapter I of Regulation (EC) No 853/2004 of the European Parliament (European Union, 2004a) and of the Council of 29 April 2004 (European Union, 2004b), bacterial count and SCC in raw cow milk should not exceed 100,000 and 400,000/mL, respectively. Both counts are measured in raw milk before processing, and their values indicate the health status of the mammary gland. Hygiene requirements for animals in production herds preclude milk collection from sick animals. Noncompliance with hygiene requirements creates a serious hazard for consumers' health because microbiologically contaminated raw milk may be a source of microorganisms pathogenic for humans and of milkborne diseases. Occurrence of milkborne diseases is more frequent in humans consuming raw milk than in those consuming pasteurized milk. Studies in the United States revealed 12 confirmed outbreaks of human diseases related to consumption of raw milk between 2002 and 2008, which were caused by Listeria monocytogenes (1 outbreak), Campylobacter spp. (5 outbreaks), Salmonella spp. (4 outbreaks), and verotoxic Escherichia coli (2 outbreaks; Oliver et al., 2009). According to a report of the European Food Safety Authority (EFSA) and the European Centre for Disease Prevention and Control (ECDC) from 2010 (EFSA-ECDC, 2012), Campylobacter spp. bacteria were found in samples of raw milk collected in 4 countries of the European Union; namely, Germany, Italy, Hungary, and Slovakia. These bacteria were the causative factor of human disease in 3 confirmed campylobacteriosis outbreaks (8.1\%) in the European Union. Studies performed in the European Union revealed that $3.7 \%$ of samples of raw milk for consumption were contaminated with L. monocytogenes, whereas $2.6 \%$ of samples in Belgium and 5.3\% of samples in Germany contained verotoxic E. coli strains. In Portugal, as many as $25.7 \%$ of raw milk samples from animal farms were contaminated with Brucella spp. bacteria. Recent studies in the United States have also revealed presence of pathogenic bacteria in milk. Analyses of 248 raw milk samples (each sample from a different farm) collected 
in 16 administrative districts of Pennsylvania showed presence of Campylobacter jejuni (2\% of the samples), Shiga toxin-producing E. coli $(2.4 \%)$, L. monocytogenes (2.8\%), Salmonella (6\%), and Yersinia enterocolitica $(1.2 \%)$. Altogether, $13 \%$ of the samples were contaminated with one or more species of pathogenic microorganisms (Jayarao et al., 2006). Hayes et al. (2001) confirmed the presence of streptococci in raw milk samples collected in 13 farms, the most common being Streptococcus uberis. In Poland, $24 \%(\mathrm{n}=150)$ of raw milk samples originating from 2 farms were contaminated with 36 strains of staphylococci, 17 of which were coagulase-positive and were classified as Staphylococcus aureus (16 strains) and Staphylococcus intermedius (1 strain; Bystroń et al., 2001). Mycobacterium paratuberculosis was found in 2.47\% ( $\mathrm{n}=81)$ of milk samples from a farm in northeastern Poland, taken from cows displaying a seropositive reaction in serological tests for paratuberculosis (Szteyn et al., 2006).

Direct sale of milk is defined as direct supply of milk from producer to final consumer. According to the hygiene package [Regulation (EC) No 852/2004 and Regulation (EC) No 853/2004; European Union, 2004a,b], direct sale of milk in the European Union is regulated by the national law of the member countries. In Poland, veterinary requirements were formulated by the Minister of Agriculture and Rural Development in the regulation passed on December 29, 2006 (MARD, 2007). According to this regulation, raw milk intended for direct sale should meet, among others, all the requirements specified in Regulation (EC) No 853/2004 (European Union, 2004b). The aim of this study was to determine the microbiological quality of raw cow milk from direct sale points.

\section{MATERIALS AND METHODS}

\section{Milk Sample Collection}

Raw cow milk samples for microbiological evaluation were collected from 5 randomly selected direct sale points (labeled as A, B, C, D, and E) located in eastern Poland. Samples were collected between November 2013 and January 2014. Each milk sample consisted of $500 \mathrm{~mL}$ of raw milk collected into a sterile container. In total, 50 samples, divided into 5 groups of 10 samples from each point (groups A, B, C, D and E), were microbiologically evaluated. Temperature of milk storage at the sale points was maintained between $2.5^{\circ} \mathrm{C}$ and $4.0^{\circ} \mathrm{C}$. The samples were delivered to the microbiological laboratory within $1 \mathrm{~h}$ of collection and maintained at a temperature between $0^{\circ} \mathrm{C}$ and $4.0^{\circ} \mathrm{C}$ during transport.

\section{Microbiological Evaluation and Determination of SCC and Inhibitory Substances}

Raw milk samples were analyzed to determine total aerobic bacterial count (TBC), SCC, and counts of Enterobacteriaceae, Enterococcus, E. coli, and Staphylococcus, as well as presence of Salmonella, L. monocytogenes, and inhibitory substances (antibiotics, detergents, and disinfectants). Except for Enterococcus, bacterial classification was performed according to the ISO (International Organization for Standardization) standards (ISO, 1999, 2001, 2004a,b, 2005, 2009a); Enterococcus count was determined according to Polish Standard (1997).

Bacteria from the Enterobacteriaceae family were identified using Enterotest $24 \mathrm{~N}$ kit (Erba Lachema, Brno, Czech Republic). Staphylococcus aureus was classified via analysis of the biochemical profile with Staphytest 24 (Erba Lachema). A PCR method was used to identify L. monocytogenes; DNA isolation was performed using the DNA-Genomic Mini AX Bacteria Kit (catalog number 060-60; A\&A Biotechnology, Gdynia, Poland), and the amplification reaction for $L$. monocytogenes was carried out using a PCR kit (cat. number K 069, Genekan Biotechnology AG, Duisburg, Germany) and agarose gel (Agarose Serva, cat. number 11404, Serva Electrophoresis GmbH, Heidelberg, Germany). Electrophoretic horizontal separation was performed with a 15-well Mini-Sub Cell GT System (Bio-Rad Laboratories Inc., Hercules, CA) and a DNA size marker (DNA Marker 1, cat. number 3000-500, A\&A Biotechnology).

Somatic cell count was determined using instrumental method accredited for 1,000 to 10,000,000 somatic cells/mL (described in detail in ISO, 2009b) with Fossomatic 5000 assay (Foss, Eden Prairie, MN).

Presence of antibiotic residues and inhibitory substances (detergents and disinfectants) was evaluated using a microbiological method (ISO, 2006) with Polutest MS test kit (Lab-Mlek Sp. z o.o., Olsztyn, Poland).

\section{Statistical Analysis}

The study was performed as factorial experiment in a completely randomized design. The obtained values of quantitative bacterial contamination (expressed as log of cfu per $/ \mathrm{mL}$ ) and SCC were analyzed using Statistica software (version 6.0, Statsoft Inc., Tulsa, OK). All values are presented as means \pm standard deviations. Statistical differences between groups of samples A, B, $\mathrm{C}, \mathrm{D}$, and $\mathrm{E}$ from particular direct sale points were determined by one-way ANOVA and Tukey's multiple comparison post hoc test; $P<0.05$ was considered as 
statistically significant. Pearson correlation coefficient (r) was determined for the selected parameters of milk samples obtained from all sale points; $P<0.05$ was assumed as statistically significant for all correlations.

\section{RESULTS AND DISCUSSION}

The mean TBC in milk collected from 5 direct sale points (A, B, C, D, and E) are shown in Table 1. Mean TBC in milk from all sale points were similar and ranged from 6.33 to $6.73 \log \mathrm{cfu} / \mathrm{mL}$, and differences in bacterial contamination observed between samples from particular points (A, B, C, D, and E) were not statistically significant. Mean values of total aerobic bacterial counts in samples from all direct sale points were between $9.2 \times 10^{4}$ and $3.6 \times 10^{7}(4.96-7.56 \mathrm{log})$ $\mathrm{cfu} / \mathrm{mL}$. The TBC exceeded the maximum acceptable level $\left(1.0 \times 10^{5}\right.$ bacteria $\left./ \mathrm{mL}\right)$ in $98 \%$ of the samples. These results concur with results of other studies that have shown that the maximum acceptable level of aerobic bacteria in milk samples is frequently exceeded. For example, $5.4 \%$ of 855 raw milk samples from farms in New York State examined in 1993 to 1996 were contaminated with aerobic bacteria at counts exceeding the maximum acceptable level. Total aerobic bacterial count in those samples ranged from $1.0 \times 10^{5} \mathrm{cfu} / \mathrm{mL}$ to more than $5.0 \times 10^{6} \mathrm{cfu} / \mathrm{mL}$ (Boor et al., 1998). Significantly higher bacterial contamination was detected in 120 milk samples collected in 3 regions (60 farms) in Khartoum State (Sudan) between August 2003 and January 2004. Total aerobic bacterial counts in that study were $4.0 \times 10^{5}-3.3 \times 10^{11}, 1.8 \times 10^{6}-1.4 \times 10^{9}$, and $5.0 \times 10^{5}-5.2 \times 10^{9} \mathrm{cfu} / \mathrm{mL}(5.6-11.52,6.26-9.16$, and 5.7-9.72 log cfu/mL), for the 3 regions, respectively. Studies performed in Khartoum State also demonstrated a significant influence of season on TBC, which ranged from $7.7 \times 10^{5}$ to $3.3 \times 10^{11}(5.87-11.52 \mathrm{log})$ $\mathrm{cfu} / \mathrm{mL}$ during the summer, and from $4.0 \times 10^{5}$ to 1.4 $\times 10^{9}(5.6-9.15 \mathrm{log}) \mathrm{cfu} / \mathrm{mL}$ during the winter (Ibtisam et al., 2007). Season-related effects on microbiological contamination of milk with aerobic bacteria were also observed in investigations of 235 milk cow herds in Prince Edward Island (Canada), between March 2005 and March 2007 (Elmoslemany et al., 2009), as well as in year-round studies on 1,144 farms on the Balearic Islands (Soler and Ponsell, 1995). Results obtained in the current study agree with observations by Pantoja et al. (2009), who reported aerobic bacterial contamination at a level of $2.0 \times 10^{6}(6.3 \mathrm{log}) \mathrm{cfu} / \mathrm{mL}$ in milk harvested using a modern milking system. High TBC in the analyzed milk, which exceeds international hygiene standards for raw milk, indicates inadequate supervision of production hygiene and storage conditions. According to Murphy and Boor (2000), a total aerobic bacterial count in excess of $1.0 \times 10^{5} \mathrm{cfu} / \mathrm{mL}$ cannot represent natural bacterial flora and is rarely possible during mastitis. It should, therefore, be ascribed to contaminated equipment and insufficient milk cooling.

Other microbiological studies prove the feasibility of satisfying hygiene requirements for raw milk. Aerobic bacterial counts acceptable under international microbiological standards were found in milk samples obtained from French dairy farms classified into 3 groups that differed in mammary gland hygiene, milking system, and environmental conditions, among other factors. Total aerobic bacterial counts from the 3 groups amounted, respectively, to $6.4 \times 10^{3}, 5.0 \times 10^{3}$, and $1.6 \times 10^{4}(3.80 \log , 3.70 \mathrm{log}$, and $4.20 \log ) \mathrm{cfu} / \mathrm{mL}$ (Verdier-Metz et al., 2009). In studies on dairy herds in Canada, $70.8 \%(\mathrm{n}=11,099)$ of raw milk samples met the international standard of $<1.0 \times 10^{5}$ aerobic bacteria in $1 \mathrm{~mL}$ of milk (Elmoslemany et al., 2009).

Compliance with hygiene rules is necessary to ensure high quality of milk. Analyses of raw milk in Serbia

Table 1. Mean values of bacterial contamination $(\log \mathrm{cfu} / \mathrm{mL})$ and $\mathrm{SCC}\left(\times 10^{3}\right.$ cells $\left./ \mathrm{mL}\right)$ for raw milk from individual direct sale points $(\mathrm{A}$, B, $\mathrm{C}, \mathrm{D}$, or $\mathrm{E} ; \mathrm{n}=10)$ and all direct sale points $(\mathrm{A}-\mathrm{E} ; \mathrm{n}=50)$

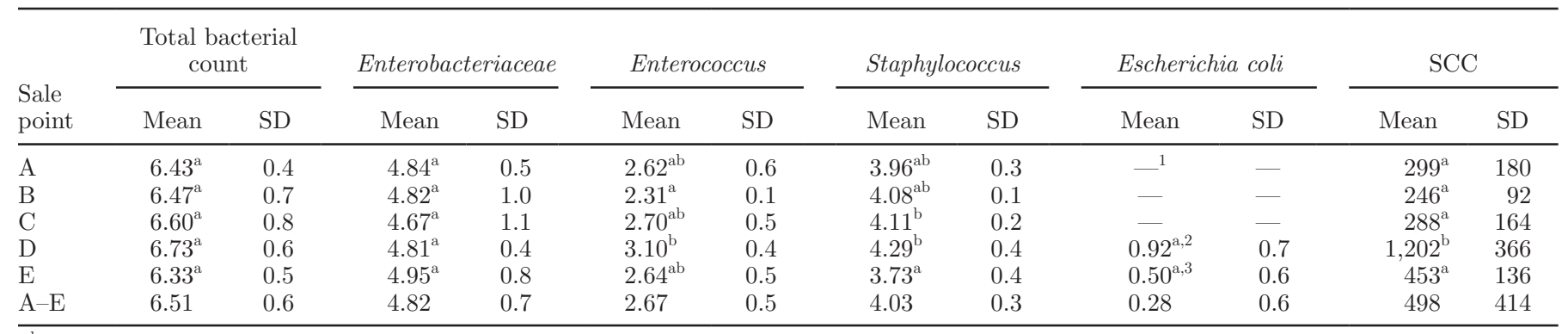

\footnotetext{
a,b Mean values within columns marked with different letters differ significantly at $P<0.05$.

${ }^{1}$ Absence of $E$. coli in all samples.

${ }^{2}$ Absence of $E$. coli in 3 samples.

${ }^{3}$ Absence of $E$. coli in 5 samples.
} 
demonstrated significant positive effects of improvements in animal breeding conditions, milk harvesting, and milk storage on compliance with good hygienic practice (GHP) and good manufacturing practice (GMP). In the first year of a 4-yr study (2006-2009) in Serbia, $55.53 \%(\mathrm{n}=45,600)$ of milk samples had a TBC exceeding $1.0 \times 10^{6} \mathrm{cfu} / \mathrm{mL}$. In the subsequent 2 yr, the percentage of such samples decreased, respectively, to 52.84 and $50.15 \%$, and in the fourth year, it was reduced to $20.3 \%$ (Smigic et al., 2012).

The present study of milk samples collected from 5 direct sale points $(\mathrm{A}, \mathrm{B}, \mathrm{C}, \mathrm{D}$, and $\mathrm{E} ; \mathrm{n}=50)$ revealed counts of Enterobacteriaceae ranging from $6.4 \times 10^{1}$ to $1.7 \times 10^{6}(1.81-6.23 \mathrm{log}) \mathrm{cfu} / \mathrm{mL}$. Mean counts of Enterobacteriaceae in milk samples ranged from $4.7 \times$ $10^{4}$ to $8.9 \times 10^{4} \mathrm{cfu} / \mathrm{mL}(4.67-4.95 \mathrm{log}$ in sale points $\mathrm{C}$ and E) and did not differ significantly (Table 1). In the present study, the most frequently isolated bacteria were Klebsiella pneumoniae ssp. ozaenae. Klebsiella pneumoniae was also isolated from cooled and noncooled raw milk samples in studies performed in France (Lafarge et al., 2004).

Enterobacteriaceae counts in milk reported by Ibtisam et al. (2007), from 0 to $1.5 \times 10^{10} \mathrm{cfu} / \mathrm{mL}(0-10.18$ $\log$ ), were both below and above the values observed in the present study. Those authors analyzed 120 milk samples from 60 large farms in Khartoum State, Sudan, between August 2003 and January 2004 (Ibtisam et al., 2007).

Presence of both Enterobacteriaceae and Enterococcus results from secondary bacterial milk contamination during milking. Enterobacteriaceae and Enterococcus counts in milk are useful indicators of hygiene conditions at this stage of the production cycle, and for this reason, both counts were measured in the present study, even though their evaluation is not required by law. In this study, Enterococcus counts in milk samples ranged from $1.1 \times 10^{2}(2.04 \mathrm{log}) \mathrm{cfu} / \mathrm{mL}$ in group $\mathrm{E}$ to $7.3 \times 10^{3}(3.86 \mathrm{log}) \mathrm{cfu} / \mathrm{mL}$ in group A. Mean counts of enterococci in samples from 5 direct sale points ranged from $2.05 \times 10^{2}$ in group B to $1.25 \times 10^{3}$ in group D (2.31 $\log$ and $3.10 \log ) \mathrm{cfu} / \mathrm{mL}$ (Table 1). Statistically significant differences were found only between groups $\mathrm{B}$ and D. Because of a lack of data on enterococci counts in the literature, these results cannot be compared with other reports.

Counts of E. coli ranging from $5.0 \times 10^{\circ}$ to $1.1 \times 10^{2}$ $\mathrm{cfu} / \mathrm{mL}$ were detected in 12 milk samples from groups $\mathrm{D}$ and $\mathrm{E}$ (Table 1). The 38 remaining milk samples from these groups were free of $E$. coli. Mean counts of E. coli were $8.0 \times 10^{\circ}(0.92 \log ) \mathrm{cfu} / \mathrm{mL}$ in group D and $3.0 \times 10^{\circ}(0.5 \mathrm{log}) \mathrm{cfu} / \mathrm{mL}$ in group $\mathrm{E}$.

Coliform bacteria, including E. coli, are not part of the natural bacterial flora of milk and rarely occur dur- ing mastitis. Their presence may be a consequence of insufficient hygiene status of animals, environmental conditions, or bacterial contamination of the milking equipment (Murphy and Boor, 2000). Comparison of these data with other reports is problematic, because $E$. coli counts were not determined in similar studies, except for coliform counts, which ranged from 0 to 1.5 $\times 10^{10}(0-10.18 \mathrm{log}) \mathrm{cfu} / \mathrm{mL}$ (Ibtisam et al., 2007). Coliform bacteria were also found in milk samples obtained between December 1993 and January 1996 from 11 dairy farms in New York State, representing approximately $10 \%$ of all farms in the state. The coliform bacteria count amounted to $\leq 10 \mathrm{cfu} / \mathrm{mL}$ in $23 \%$ of all 855 samples examined and to $<100 \mathrm{cfu} / \mathrm{mL}$ in the remaining $77 \%$ of the samples (Boor et al., 1998). Coliform counts between 0 and $3.3 \times 10^{1}(0-1.52 \mathrm{log})$ $\mathrm{cfu} / \mathrm{mL}$ were also detected in milk samples from dairies that used modern systems of milk harvesting, storage, and shipment, and participated in an intensive program of milk quality monitoring in 2006-2007 (Pantoja et al., 2009).

In the present study, Staphylococcus spp. bacteria were found in all milk samples, and their number ranged from $1.6 \times 10^{3}$ to $5.1 \times 10^{4}(3.2-4.71 \mathrm{log}) \mathrm{cfu} /$ $\mathrm{mL}$. Mean counts of Staphylococcus spp. in particular groups of samples are presented in Table 1. Statistically significant differences $(P<0.05)$ in Staphylococcus spp. counts were observed between the samples from group $\mathrm{E}\left[5.4 \times 10^{3}(3.73 \mathrm{log}) \mathrm{cfu} / \mathrm{mL}\right]$ and those from groups $\mathrm{C}\left[1.3 \times 10^{4}(4.11 \mathrm{log}) \mathrm{cfu} / \mathrm{mL}\right]$ and $\mathrm{D}\left[1.95 \times 10^{4}\right.$ $(4.29 \log ) \mathrm{cfu} / \mathrm{mL}]$. One milk sample from group E was contaminated with Staph. aureus. In the remaining samples, the most frequently isolated staphylococci were Staphylococcus hominis ssp. hominis, Staphylococcus chromogenes, Staphylococcus epidermidis, Staphylococcus capitis ssp. capitis, Staphylococcus caprae, and Staphylococcus warneri. Higher bacterial contamination of raw milk with Staphylococcus spp., of up to $2.1 \times$ $10^{9}(9.32 \log ) \mathrm{cfu} / \mathrm{mL}$, has been reported by other authors. Ranges of contamination with Staphylococcus spp. of milk from dairy farms in 3 cities of Khartoum State (Sudan) were as follows: $2.0 \times 10^{3}$ to $2.1 \times 10^{9}$ (3.3-9.32 log), 0 to $1.1 \times 10^{9}(0-9.04 \log )$, and 0 to 3.2 $\times 10^{6}(0-6.51 \mathrm{log}) \mathrm{cfu} / \mathrm{mL}$. Level of contamination with Staphylococcus spp. ranged from 0 to $2.1 \times 10^{9}(9.32$ $\log ) \mathrm{cfu} / \mathrm{mL}$ in the summer, and from 0 to $3.2 \times 10^{6}$ $(6.51 \mathrm{log}) \mathrm{cfu} / \mathrm{mL}$ in the winter (Ibtisam et al., 2007). As reported by Bystroń et al. (2001), Staphylococcus spp. bacteria were also detected in milk samples from dairy cows kept in 2 different cowsheds considered free of clinical mastitis, as well as in swabs taken from milking equipment and milk containers after they had been cleaned and disinfected. Staphylococcus spp. bacteria were present in $16 \%$ of all samples examined in that 
study. Altogether, 36 different strains of Staphylococcus bacteria were isolated from the milk samples and 4 strains from the swabs. These included 17 coagulasepositive strains found in milk and 2 coagulase-positive strains detected in the swabs (Bystron et al., 2001). Staphylococcus aureus were also isolated from milk samples taken in French dairy farms maintaining high hygiene standards of mammary glands, milking equipment, and the surrounding environment (Verdier-Metz et al., 2009).

In the current study, after evaluation of bacterial cultures, 24 bacterial strains isolated from all groups of samples (A-E) were qualified for PCR analysis to differentiate Listeria strains. Listeria monocytogenes were detected in one sample of group D (Figure 1). Listeria spp. in raw milk were detected more frequently in other studies than in the present study. They were present in $23 \%$ of raw milk samples $(\mathrm{n}=1,300)$ collected near Mexico City (Mexico) and analyzed between June 1998 and June 1999. Of those bacterial strains, $13 \%$ were classified as L. monocytogenes, $6 \%$ as Listeria ivanovii, $45 \%$ as Listeria seeligeri, and $1 \%$ as Listeria innocua (Vázquez-Salinas et al., 2001). Listeria monocytogenes and L. innocua were also detected, respectively, in 3.63 and $2.71 \%$ of raw milk samples $(\mathrm{n}=774)$ collected in Spain. Those samples were aseptically collected twice per season over 1 yr from 114 farms (Gaya et al., 1998). In studies performed in India between 2002 and 2004, Listeria strains were identified in $6.74 \%$ of raw milk samples $(\mathrm{n}=2,060): 5.1 \%$ of the samples were contaminated with $L$. monocytogenes, $0.1 \%$ with $L$. seeligeri, $0.9 \%$ with $L$. innocua, and $0.1 \%$ with Listeria welshimeri (Kalorey et al., 2008). Risk of bacterial contamination of raw milk with $L$. monocytogenes can be significantly reduced by ensuring high quality of silage and rigorous hygiene standards of milking and cow care (Sanaa et al., 1993).

Table 1 presents mean SCC for raw milk samples from sale points A, B, C, D, and E; SCC ranged from 78,000 to $1,730,000$ cells/mL. Sixty-two percent of samples analyzed in the present study fulfilled the requirements of EC Regulation 853/2004 (European Union, $2004 \mathrm{~b}$; SCC $\leq 400,000$ cells $/ \mathrm{mL}$ ), whereas $38 \%$ of the samples exceeded these norms. Statistically significant differences $(P<0.05)$ in SCC were found between group D (in which SCC was the highest) and the other groups. The SCC in group D ranged from 711,000 to 1,623,000 cells/mL (mean 1,202,000 cells/mL), exceeding the maximum acceptable level for raw milk in all samples. In group E, 7 samples exceeded the maximum acceptable SCC in raw milk, whereas groups A and C contained 1 such sample each. Somatic cell counts $>400,000$ cells $/ \mathrm{mL}$ of raw milk indicate clinical mastitis in cows. Milk from such cows should not be offered to consumers (European Union, 2004b). In group B, SCC was the lowest, ranging from 93,000 to 373,000 cells/ $\mathrm{mL}$, and all samples from this group met the requirements of EC Regulation 853/2004 (European Union, 2004b). Somatic cell counts in excess of the maximum acceptable level have been reported in other studies. In Prince Edward Island, 8.7\% ( $\mathrm{n}=22,714)$ of raw milk samples from dairy farms were characterized by SCC $>400,000$ cells $/ \mathrm{mL}$. An effect of season on SCC in milk was also observed, as counts were higher in summer (Elmoslemany et al., 2009). Somatic cell counts ranging from 126,000 to 286,000 cells $/ \mathrm{mL}$ were found in raw milk samples $(\mathrm{n}=9,626)$ from dairy farms with modern milking and storing systems, advanced milk transportation systems, and milk quality monitoring program (Pantoja et al., 2009). Relatively low SCC values $(100,000-150,000$ cells $/ \mathrm{mL})$ were noted in all milk samples $(\mathrm{n}=68)$ from dairy farms in Burkina Faso, and the values did not differ significantly between particular cows and farms. Somatic cell counts in those

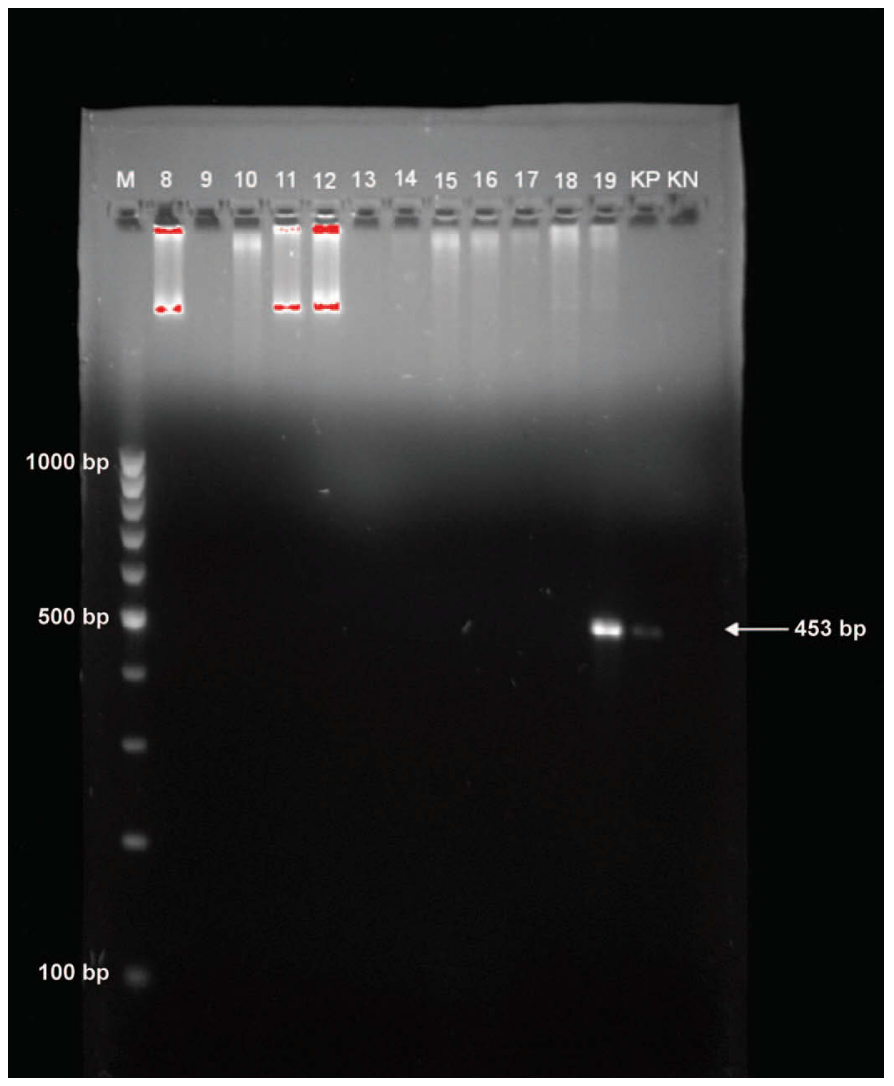

Figure 1. Electrophoretogram (2\% agarose gel) with a PCR assay for the identification of Listeria monocytogenes DNA. M = molecularweight size marker (DNA ladder from 100 to 1,000 bp); KP = positive control (amplified fragment of $453 \mathrm{bp}$ ); $\mathrm{KN}=$ negative control; lanes 8 to 19 represent from 8 to 19 PCR products of DNA isolated from various rods of Listeria spp. Color version available online. 
Table 2. Pearson correlation coefficients $(\mathrm{r})$ between the parameters of milk samples from all direct sale points A to $\mathrm{E}(\mathrm{n}=50)$

\begin{tabular}{lcccc}
\hline Count & Enterobacteriaceae & Enterococcus & Staphylococcus & Escherichia coli \\
\hline Total bacterial count & $0.35^{*}$ & 0.07 & $0.44^{*}$ & 0.06 \\
Enterococcus & -0.15 & & 0.05 & $0.32^{*}$ \\
Staphylococcus & -0.08 & 0.05 & $0.53^{*}$ & 0.1 \\
E. coli & 0.01 & $0.32^{*}$ & 0.10 & 0.23 \\
SCC & 0.03 & $0.53^{*}$ & 0.23 & $0.74^{*}$ \\
\hline
\end{tabular}

*Statistically significant correlation at $P<0.05$.

samples were not affected by season of the year (dry and wet seasons) (Millogo et al., 2010).

A relationship exists between SCC in milk and education (broadly defined) of dairy farm owners, which affects the management of farms where the milk is produced (Barkema et al., 1999). As shown by Chassagne et al. (2005), the living conditions of cows and proper milking procedures are crucial to maintaining optimal SCC in milk.

In the present study, no Salmonella rods were detected in any of the samples. Other authors, however, have reported the presence of these microorganisms in milk. Van Kessel et al. (2004) found 9 Salmonella serotypes in $2.6 \%(\mathrm{n}=821)$ of raw milk samples collected in 21 US states. In Italy, Salmonella spp. were detected in $0.3 \%$ of raw milk samples $(\mathrm{n}=618)$ examined in 2009-2010 (Bianchi et al., 2013).

Samples examined in the current study contained no inhibitory substances. Other authors, depending on the laboratory test used, detected inhibitory substances such as penicillin, gentamycin, and chloramphenicol, in 1.2 to $1.5 \%$ of 337 samples of milk for the consumer market in Belgium, Denmark, Germany, French, Great Britain, Ireland, the Netherlands, Norway, and Sweden (Suhren et al., 1990). In Poland, inhibitory substances were found, depending on the analytical method used, in 13.1 to $22.4 \%$ of raw milk samples, in 10.5 to $19.5 \%$ of consumer milk samples, and in 12.9 to $18.2 \%$ of milk powder samples examined in 1990-1993 ( $\mathrm{n}=16,334$; Rybińska et al., 1995). Inhibitory substances were also present in $2.9 \%(\mathrm{n}=1,259)$ of raw milk samples examined in Croatia in 2008-2010 (Bilandżić et al., 2011).

\section{Correlations Between Milk Quality Parameters}

Interrelationships between quality parameters of milk from 5 direct sale points are presented in Table 2. Statistically significant positive correlations were found between TBC and Staphylococcus count $(\mathrm{r}=0.44 ; P$ $<0.05)$ and Enterobacteriaceae count $(\mathrm{r}=0.35 ; P<$ $0.05)$; between SCC and Enterococcus count $(\mathrm{r}=0.53$; $P<0.05)$ and $E$. coli count $(\mathrm{r}=0.74 ; P<0.05)$; and between E. coli count and Enterococcus count $(\mathrm{r}=0.32$; $P<0.05)$. All other correlations between milk quality parameters were relatively low and statistically nonsignificant $(-0.15<\mathrm{r} \leq 0.23$; all $P>0.05)$.

Interrelationships between milk quality parameters determined for groups of samples from each direct sale point are shown in Table 3. Statistically significant negative correlations were found between Enterobacteriaceae and Staphylococcus counts $(\mathrm{r}=-0.74 ; P<0.05)$ in group C; between Enterobacteriaceae and Enterococcus counts $(\mathrm{r}=-0.64 ; P<0.05)$ and between $E$. coli and Staphylococcus counts $(\mathrm{r}=-0.66 ; P<0.05)$ in group E; and between TBC and Staphylococcus count $(\mathrm{r}=0.78 ; P<0.05)$ in group D. Statistically significant positive correlations were found between SCC and $E$. coli count $(\mathrm{r}=0.73 ; P<0.05)$ in group $\mathrm{D}$, as well as between SCC and Enterobacteriaceae count $(\mathrm{r}=0.73 ; P$ $<0.05$ ) in group B. All other correlations between milk quality parameters determined for milk from particular sale points were not statistically significant, even when relatively high $(-0.57 \leq \mathrm{r} \leq 0.56$; all $P>0.05)$. No statistically significant correlations between milk quality parameters were found in group A. Significant correlations of the parameters observed within particular groups of samples $(\mathrm{n}=10)$ were not confirmed by the combined results for all samples $(\mathrm{n}=50)$, except for the positive correlation between SCC and the E. coli count in group E, where nearly identical correlation coefficients were obtained for both calculations.

\section{CONCLUSIONS}

In the samples examined in the present study, international hygiene standards were exceeded for total aerobic bacterial count (in $98 \%$ of the samples, $\mathrm{n}=48$ ) as well as for SCC (in $38 \%$ of the samples, $\mathrm{n}=19$ ). The obtained results from all 5 direct milk sale points (A-E) indicated strong positive correlation of SCC with Enterococcus count and E. coli count. Two milk samples contained pathogenic bacteria (L. monocytogenes and Staph. aureus) that pose potential hazards for consumer health. These results indicate inadequate hygiene during harvesting of milk offered for sale in all 5 direct sale points (groups $\mathrm{A}-\mathrm{E}$ ), which would account for excessive TBC and SCC, as well as for presence of pathogenic bacteria in some milk samples. 
Table 3. Pearson correlation coefficients $(\mathrm{r})$ between the parameters of milk samples from particular direct sale points $\mathrm{A}, \mathrm{B}, \mathrm{C}, \mathrm{D}$, and $\mathrm{E}(\mathrm{n}=10$ in each group)

\begin{tabular}{llccc}
\hline Sale point & Count & Staphylococcus & Enterococcus & SCC \\
\hline B & Enterobacteriaceae & -0.57 & -0.14 & $0.73^{*}$ \\
C & & $-0.74^{*}$ & -0.11 & 0.24 \\
E & & 0.36 & $-0.64^{*}$ & -0.52 \\
E & Escherichia coli & $-0.66^{*}$ & 0.15 & 0.39 \\
D & & -0.13 & 0.14 & $0.73^{*}$ \\
D & Total bacterial count & $0.78^{*}$ & 0.46 & 0.22 \\
\hline
\end{tabular}

*Statistically significant correlations at $P<0.05$.

Such significant bacterial contamination of milk most probably occurs at the milking stage of the production cycle and may be related to the subsequent insufficient milk cooling. Milk at direct milk sale points is stored at $2.5^{\circ} \mathrm{C}$ to $4^{\circ} \mathrm{C}$ and must be sold within $24 \mathrm{~h}$, which precludes the possibility of intensive bacterial growth such as that observed in the present study. To improve the hygiene quality of milk offered through direct sale points, it is necessary to increase compliance with good hygienic practices and to provide appropriate training to farm staff responsible for milking and animal care. Improved monitoring of the health status of dairy cows, especially of the mammary gland, is also recommended to eliminate cases of subclinical mastitis, occurrence of which is suggested by the results obtained in this study. Coexisting mastitis may also have contributed to high bacterial contamination of the milk samples. The above recommendations should be applied to production of milk for direct sale not only in Poland, but also in other countries, as demonstrated by the literature data on bacterial contamination of such milk.

\section{REFERENCES}

Barkema, H. W., J. D. Van der Ploeg, Y. H. Schukken, T. J. G. M. Lam, G. Benedictus, and A. Brand. 1999. Management style and its association with bulk milk somatic cell count and incidence rate of clinical mastitis. J. Dairy Sci. 82:1655-1663.

Bianchi, D. M., A. Barbaro, S. Gallina, N. Vitale, L. Chiavacci, M Caramelli, and L. Decastelli. 2013. Monitoring of foodborne pathogenic bacteria in vending machine raw milk in Piedmont, Italy. Food Contr. 32:435-439.

Bilandżić, N., B. S. Kolanowić, I. Varenina, G. Scortichini, L. Annunziata, M. Brstilo, and N. Rudan. 2011. Veterinary drug residues determination in raw milk in Croatia. Food Contr. 22:1941-1948.

Boor, K. J., D. P. Brown, S. C. Murphy, S. M. Kozlowski, and D. K. Bandler. 1998. Microbiological and chemical quality of raw milk in New York State. J. Dairy Sci. 81:1743-1748.

Bystroń, J., K. Paszkowska-Kosek, and J. Molenda. 2001. Occurrence of enterotoxigenic staphylococci in raw milk. Med. Weter. 57:645648 .

Chassagne, M., J. Barnouin, and M. Le Guenic. 2005. Expert assessment study of milking and hygiene practices characterizing very low somatic cell score herds in France. J. Dairy Sci. 88:1909-1916.

EFSA-ECDC. 2012. Scientific Report of EFSA and ECDC: The European Union summary report on trends and sources of zoonoses, zoonotic agents and food-borne outbreaks in 2010. EFSA J. 10:2597.
Elmoslemany, A. M., G. P. Keefe, I. R. Dohoo, and R. T. Dingwell. 2009. Microbiological quality of bulk tank raw milk in Prince Edward Island dairy herds. J. Dairy Sci. 92:4239-4248.

European Union. 2004a. Regulation (EC) No 852/2004 of the European Parliament and of the Council of 29 April 2004-On the hygiene of foodstuffs. Off. J. L139:1-54.

European Union. 2004b. Regulation (EC) No 853/2004 of the European Parliament and of the Council of 29 April 2004-Laying down specific hygiene rules for food of animal origin. Off. J. L139:55-205.

Gaya, P., J. Sanchez, M. Medina, and M. Nuñez. 1998. Incidence of Listeria monocytogenes and other Listeria species in raw milk produced in Spain. Food Microbiol. 15:551-555.

Hayes, M. C., R. D. Ralyea, S. C. Murphy, N. R. Carey, J. M. Scarlett, and K. J. Boor. 2001. Identification and characterization of elevated microbial counts in bulk tank raw milk. J. Dairy Sci. 84:292-298.

Ibtisam, E., M. El Zubeir, and I. A. Ahmed Mahboba. 2007. The hygienic quality of raw milk produced by some dairy farms in Khartoum State, Sudan. Res. J. Microbiol. 2:988-991.

ISO (International Organization for Standardization). 1999. PN-EN ISO 11290-1: Microbiology of food and animal feeding stuffsHorizontal method for the detection and enumeration of Listeria monocytogenes-Part 1: Detection method. ISO, Geneva, Switzerland.

ISO (International Organization for Standardization). 2001. PN-EN ISO 6888-1: Microbiology of food and animal feeding stuffs-Horizontal method for the enumeration of coagulase-positive staphylococci (Staphylococcus aureus and other species)-Part 1: Technique using Baird-Parker agar medium. ISO, Geneva, Switzerland.

ISO (International Organization for Standardization). 2004a. PN-EN ISO 4833: Microbiology of food and animal feeding stuffs-Horizontal method for the enumeration of microorganisms-Colonycount technique at $30^{\circ} \mathrm{C}$. ISO, Geneva, Switzerland.

ISO (International Organization for Standardization). 2004b. PN-ISO 16649-2: Microbiology of food and animal feeding stuffs-Horizontal method for the enumeration of beta-glucuronidase-positive Escherichia coli-Part 2: Colony-count technique at 44 degrees C using 5-bromo-4-chloro-3-indolyl beta-D-glucuronide. ISO, Geneva, Switzerland.

ISO (International Organization for Standardization). 2005. PN-ISO 21528-2: Microbiology of food and animal feeding stuffs-Horizontal method for the detection and enumeration of Enterobacteriaceae-Part 2: Colony-count method. ISO, Geneva, Switzerland.

ISO (International Organization for Standardization). 2006. PN-EN ISO 13969: Milk and milk products - Guidelines for a standardized description of microbial inhibitor tests. ISO, Geneva, Switzerland.

ISO (International Organization for Standardization). 2009a. PN-EN ISO 6785: Milk and milk products-Detection of Salmonella spp. ISO, Geneva, Switzerland.

ISO (International Organization for Standardization). 2009b. PN-EN ISO 13366-2: Milk-Enumeration of somatic cells-Part 2: Guidance on the operation of fluoro-opto-electronic counters. ISO, Geneva, Switzerland.

Jayarao, B. M., B. A. Donaldson, B. A. Straley, A. A. Sawant, N. V. Hegde, and J. L. Brown. 2006. A survey of foodborne pathogens in bulk tank milk and raw milk consumption among farm families in Pennsylvania. J. Dairy Sci. 89:2451-2458. 
Kalorey, D. R., S. R. Warke, N. V. Kurkure, D. B. Rawool, and S. B. Barbuddhe. 2008. Listeria species in bovine raw milk: A large survey of Central India. Food Contr. 19:109-112.

Lafarge, V., J. C. Ogier, V. Girard, V. Maladen, J. Y. Leveau, A. Gruss, and A. Delacroix-Buchet. 2004. Raw cow milk bacterial population shifts attributable to refrigeration. Appl. Environ. Microbiol. 70:5644-5650.

MARD (Minister of Agriculture and Rural Development). 2007. Regulation of the Minister of Agriculture and Rural Development from 29 December 2006 - On veterinary requirements at the production of products of the animal origin intended direct sales. Journal of Laws 2007, No 5, item 38. Government Legislation Centre, Warsaw, Poland.

Millogo, V., K. Svennersten Sjaunja, G. A. Ouédraogo, and S. Agenäs. 2010. Raw milk hygiene at farms, processing units and local markets in Burkina Faso. Food Contr. 21:1070-1074.

Murphy, S. C., and K. J. Boor. 2000. Trouble-shooting sources and causes of high bacteria counts in raw milk. Dairy Food Environ. Sanit. 20:606-611.

Oliver, S. P., K. J. Boor, S. C. Murphy, and S. E. Murinda. 2009. Food safety hazards associated with consumption of raw milk. Foodborne Pathog. Dis. 6:793-806.

Pantoja, J. C. F., D. J. Reinemann, and P. L. Ruegg. 2009. Associations among milk quality indicators in raw bulk milk. J. Dairy Sci. 92:4978-4987.

Polish Standard. 1997. PN-A-82055-7: Meat and meat products-Microbiological examination-Detection and enumeration of enterococci. Polish Committee for Standardization, Warsaw, Poland.
Rybińska, K., J. Postupolski, and M. Szczęsna. 1995. Residues of antibiotics and other inhibitory substances in milk. Rocz. Panstw. Zakl. Hig. 46:239-241.

Sanaa, M., B. Poutrel, J. L. Menard, and F. Serieys. 1993. Risk factors associated with contamination of raw milk by Listeria monocytogenes in dairy farms. J. Dairy Sci. 76:2891-2898.

Smigic, N., I. Djekic, I. Tomasevic, J. Miocinovic, and R. Gvozdenovic 2012. Implication of food safety measures on microbiological quality of raw and pasteurized milk. Food Contr. 25:728-731.

Soler, A., and C. Ponsell. 1995. The microbiological quality of milk produced in the Balearic Islands. Int. Dairy J. 5:69-74.

Suhren, G., A. Hoffmeister, J. Reichmuth, and W. Heeschen. 1990 Incidence of inhibitory substances in milk for consumption from various European countries. Milchwissenschaft 45:485-490.

Szteyn, J., A. Wiszniewska-Łaszczych, and A. Ruszczyńska. 2006. Occurrence of Mycobacterium paratuberculosis in samples of raw milk. Med. Weter. 62:1186-1197.

Van Kessel, J. S., J. S. Karns, L. Gorski, B. J. McCluskey, and M. L. Perdue. 2004. Prevalence of Salmonellae, Listeria monocytogenes and fecal coliforms in bulk tank milk on US dairies. J. Dairy Sci. $87: 2822-2830$

Vázquez-Salinas, C., O. Rodas-Suárez, and E. I. Quiñones-Ramirez. 2001. Occurrence of Listeria species in raw milk in farms on the outskirts of Mexico City. Food Microbiol. 18:177-181.

Verdier-Metz, I., V. Michel, C. Delbés, and M. Ch. Montel. 2009. Do milking practices influence the bacterial diversity of raw milk? Food Microbiol. 26:305-310. 